\title{
DOI: 10.31563/1684-7628-2018-46-2-44-49
}

Experimental data of variety tests of spring hard wheat in the agro climatic conditions of the Chuvash Republic for 2015 and 2017 are presented. In the Academic and Research Production Center «Studenchesky» of the Federal State Budgetary Educational Institution of Higher Education Chuvash State Agricultural Academy research on the ecological variety testing of five varieties of spring hard wheat has been conducted since 2015. The varieties to have been tested were: 1) Bezenchukskaya Niva; 2) Bezenchukskaya 200; 3) Bezenchukskaya 205; 4) Bezenchukskaya 209; 5) Lutch 25. The results of biometrical analysis of spring hard wheat showed that the height of the plants according to the varieties made from 74,5 to $104,75 \mathrm{~cm}$ during two years. At the same time, Bezenchukskaya 200 was the most short-grown variety, the highest plants were noted in the Bez- enchukskaya strain 205. The best productive tilling capacity was recorded in Bezenchukskaya Niva and Bezenchukskaya 209. The best indicators of the crop structure were recorded in Bezenchukskaya Niva, where the spike length was $5,1 \mathrm{~cm}$, the number of seeds in the spike was 22,9 pieces, and the weight of seeds in the spike was $1,12 \mathrm{~g}$. The least indicators are marked in Bezenchukskaya 205 , the number of seeds in a spike being 16,8 pieces, and the mass of seeds $-0,76 \mathrm{~g}$. It was found that the number and the mass of grains in a spike according to the variety changed proportionally to the length of the spike. The mass of 1,000 of seeds made from 42,32 to 53,27 grams on options. The biological yield accounting revealed the advantage of the Bezenchukskaya Niva variety of $341 \mathrm{~g} / \mathrm{sqm}$, the smallest yield productivity index of $196 \mathrm{~g}$ / sqm was marked in Bezenchukskaya 205.

УДК 633.16:631.52

DOI: $10.31563 / 1684-7628-2018-46-2-44-49$

P.A. Максимов

\section{НОВЫЙ СПОСОБ ПОСЕВА НА РАННИХ СТАДИЯХ СЕЛЕКЦИИ ЯЧМЕНЯ В УСЛОВИЯХ СРЕДНЕГО УРАЛА}

\section{Ключевые слова: ячмень; селекция; сеялка ССФК-7; ручной посев; механизированный посев.}

Введение. Несмотря на большой прогресс развития техники для селекции различных культур, все еще значительная часть работ в научных учреждениях проводится вручную, особенно на ранних этапах селекционной работы [1-8]. В 80-х годах прошлого века в большинстве селекционных учреждений была внедрена кассетная сеялка СКС-6А, что позволило выполнять посев ранних селекционных питомников. Данная сеялка внедрялась также и в Красноуфимском селекционном центре, однако из-за особенности рельефа, а также каменистости почвы очень часто механизм сеялки отказывал, в результате посев прерывался, что нарушало последовательность высева линий и семей; более того, кассеты приходилось заряжать семенами в полевых условиях, что значительно снижало производительность. После неудачных попыток эксплуатации сеялки СКС6 А в нашем учреждении было принято решение продолжать проводить посев вручную или так называемым способом «в трубу», который был разработан еще в 1979 году. Вместе с этим использовался посев ручной сеялкой СР-1, однако и этот способ был менее производителен, чем традиционный «в трубу». В 2015 г. в селекционную сеялку ССФК-7 впервые нами были вне- сены новые конструктивные изменения, что позволило проводить посев селекционного питомника 1 года, а также испытания потомств 1 года механизированно.

Цель исследования - разработать и внедрить новый механизированный способ посева селекционных питомников.

В задачи исследования входило: на основе конструктивных изменений сеялки ССФК-7 разработать новый механизированный способ посева ранних селекционных питомников; дать сравнительную характеристику нового механизированного способа посева и традиционного ручного способа.

Условия, материалы и методы исследования. Исследования проведены в 2017 г. в стационарном опыте Красноуфимского селекционного центра. Для посева в качестве исследуемой культуры использовали ячмень. Способы посева - ручной (метод «в трубу») и механизированный сеялкой ССФК-7.

Способ 1 - «в трубу». Для посева используется ровный участок. Предварительно проводится маркировка участка, размеры делянки под посев одной линии (семьи) $-70 \times 70 \mathrm{~cm}$. В качестве инвентаря для посева используется мотыга с шириной налопатника 25 см и труба 


\section{DOI: 10.31563/1684-7628-2018-46-2-44-49}

из жести (высота - 120 см, нижний диаметр 15 см, верхний диаметр - 30 см). В закладке опыта способом «в трубу» участвуют четыре человека: первый разгребает мотыгой верхний слой почвы на глубину 5-7 см, второй в образовавшуюся лунку ставит трубу, третий разрывает бумажный пакетик с семенами и движением руки выбрасывает семена так, чтобы они обязательно ударились об стенку трубы, таким образом, посевной материал относительно равномерно распределяется внутри нижнего радиуса трубы. И, наконец, четвертый работник с помощью мотыги загребает семена землей.

Способ 2 - механизированный посев сеялкой ССФК-7. Для посева используется сеялка ССФК-7 (рисунок 1).

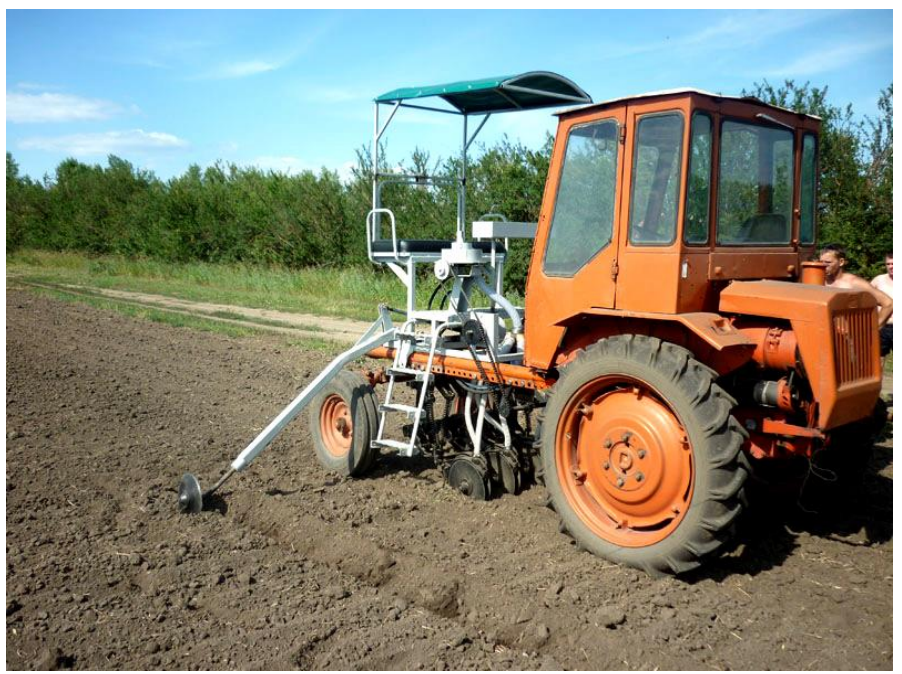

Рисунок 1

Сеялка ССФК-7

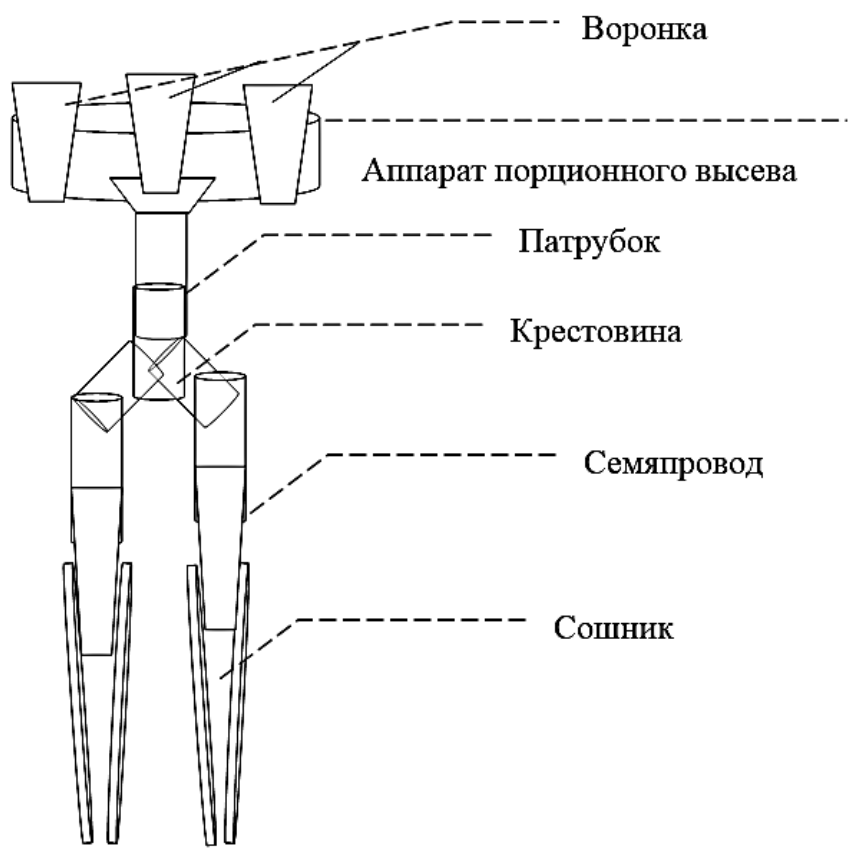

Рисунок 2

Схема высевающего аппарата сеялки ССФК-7

с изменениями для посева питомников ранних этапов селекции и первичного семеноводства

В конструкцию высевающего аппарата добавились пластмассовые воронки, которые располагаются в аппарате порционного высева, плотно прилегая к лопастям ячеек. Пластмассовые воронки располагаются равномерно, так чтобы расстояние между ними было одинако- вое; они двигаются по кругу, что обеспечивает рассев семян порциями, каждая порция - линия или семья. Семяпровод, который идет от аппарата порционного высева к центробежному распределителю семян, отсоединяется, вместо него патрубок соединяется с крестовиной, ко- 


\section{DOI: 10.31563/1684-7628-2018-46-2-44-49}

торая распределяет семена на два крайних правых сошника, остальные сошники в данном способе посева не рабочие (рисунок 2).

Итак, после дополнений в конструкцию сеялки ССФК-7 посев осуществляется следующим образом. В работе принимают участие также четыре человека - это механизатор, который управляет самоходной сеялкой, два оператора сеялки: основной и помощник, а также работник, который подает посевной материал операторам сеялки. Перед началом работы готовится участок для посева, который в длину составляет 40 м. Ширина определяется количеством проходов сеялки. Высевающий аппарат настраивается таким образом, чтобы за полный оборот барабана аппарата порционного высева осуществился посев на один цикл длиной 2,1 м, а так как на барабан устанавливаются три воронки, то на условный цикл высеваются также три линии (семьи). В итоге на проходе в 40 м всего получается 19 циклов и высевается 57 линий (семей). Сеялка движется непрерывно по всей длине (40 м), в это время основной оператор также непрерывно и поочередно высыпает в каждую воронку посевной материал.

Для удобства и непрерывности работы семена высыпаются из пластмассовых стаканчиков. Затем, после прохождения 40 м и пересекая границу яруса, сеялка разворачивается, становится на этот же прогон и возвращается в исходную точку, осуществляя посев. Крайние правые, работающие сошники теперь расположены по другую сторону прохода. На фото изображен внешний вид опыта с посевом сеялкой ССФК-7 (рисунок 3).

Так получается рассев 1 единицы посева (комбинация скрещивания), по краям которой располагаются строчки шириной и длиной 15 см, расстояние между ними в продольном направлении 55 см, в поперечном - 50 см по следу трактора и 60 см между строчками внутри прохода (холостые сошники). Всего на единице посева 114 номеров, поперечные края в дальнейшем подвергаются вырезке, в итоге остаются 100 номеров на учет и 4 «защитки». Далее процесс повторяется до высева всего объема. Таким образом, заложен опыт двумя вариантами: 1) ручной посев; 2) посев сеялкой ССФК-7. В каждом варианте было 5000 номеров. В эксперименте в первом варианте принимали участие 2 научных сотрудника и 2 лаборанта-исследователя, во втором - 2 научных сотрудника, механизатор и лаборант-исследователь. В процессе работы на каждом этапе фиксировалось время.

Результаты исследования. Площадь делянки 1 номера (линии) при ручном способе посева (РСП) составила 0,49 м², при посеве механизированным способом (МСП) - также 0,49 м². Следовательно, общая площадь вариантов одинакова - $2450 \mathrm{~m}^{2}$ (таблица). Влияние размещения кустов растений на уход за посевами, селекционные отборы и непосредственно на уборку по вариантам опыта незначительно. Уход за посевами заключался в проведении двух операций. Это механизированная обработка против сорняков в фазу кущения и ручная прополка в фазу выход в трубку - колошение. При РСП расстояние между кустами составляет 55 см во всех направлениях, во втором варианте - в продольном направлении между кустами - 55 см; по следу трактора -50 см и между двумя крайними сошниками - 60 см. Поэтому как в первом варианте опыта, так и во втором расстояние между кустами - более 45 см, что позволяет провести обработку посевов гербицидами агрегатом (МТ3 82 с навесным опрыскивателем ЗАРЯ 600-12-ОН-01). При проведении ручной прополки также не возникает особых затруднений.

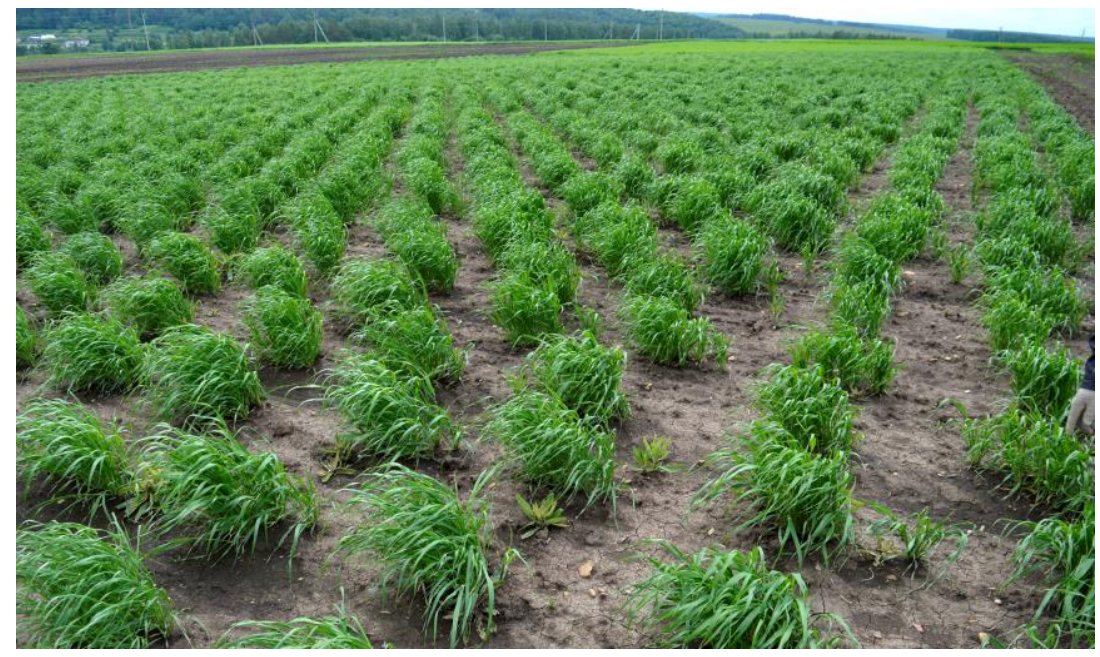

Рисунок 3

Внешний вид посева сеялкой ССФК-7 с измененной конструкцией высевающего аппарата 


\section{DOI: 10.31563/1684-7628-2018-46-2-44-49}

Таблица 1 Сравнительные результаты различных способов посева селекционных питомников 1 года, 2017 г.

\begin{tabular}{|c|l|c|c|}
\hline \multirow{2}{*}{$№$ п/п } & \multicolumn{1}{|c|}{ Показатель } & $\begin{array}{c}\text { Посев ручным } \\
\text { способом «в трубу» }\end{array}$ & $\begin{array}{c}\text { Посев механизированным } \\
\text { способом ССФК-7 }\end{array}$ \\
\hline 1 & Количество работников & 4 & 5000 \\
\hline 2 & Количество номеров (линий) & 5000 & 0,49 \\
\hline 3 & Площадь делянки 1 номера, ${ }^{2}$ & 0,49 & 2450 \\
\hline 4 & Общая площадь питомника, м² & 2450 & 714 \\
\hline 5 & Скорость посева, номеров/час & 375 & 7,0 \\
\hline 6 & Время посева, час & 13,3 & 128 \\
\hline 7 & Трудоемкость при подготовке к посеву, чел.-час & 436 & 28,0 \\
\hline 8 & Трудоемкость при посеве, всего, чел.-час & 53,2 & 52192 \\
\hline 9 & Затраты на оплату труда, руб. & 146400 & \\
\hline
\end{tabular}

Большое значение имеет продолжительность посевной, поскольку при сжатом сроке посева создаются наиболее приемлемые условия для отбора, так как растения попадают в относительно одинаковые агрометеорологические условия. В отдельные годы при больших объемах питомников посев растягивался на 6-7 дней, иногда в условиях длительного посева происходили непреднамеренные задержки из-за осадков, что еще более растягивало сроки закладки опытов. Поэтому в исследовании определялась средняя скорость посева, фиксировалось чистое время, затраченное на посев, за исключением перерывов на отдых и других моментов, связанных с обслуживанием техники. Так, при ручном способе посева в среднем за 1 час высевалось 375 номеров, при новом механизированном способе - 714, что в 1,9 раза быстрее. В результате группа работников МСП затратила на посев 7 часов и закончила работы на 6,3 часа раньше. Трудоемкость при посеве РСП составила 53,2 чел.-ч, при МСП - 32,0 чел.-ч (в 1,9 раз ниже). Ручной посев не только трудоемок, но и связан с большими затратами физической энергии, что значительно ограничивает объемы проработки селекционного материала на начальных этапах селекции, а следовательно, уменьшает вероятность создания более хорошего сорта.

Еще один важный фактор - предпосевная подготовка семенного материала. Ранее при ручном посеве требовалась упаковка семян в специальные бумажные пакеты, в новых условиях семена помещаются в пластмассовые стаканчики, этот процесс более удобен, поскольку не требуется изготовление пакетов и их сшивка. Ежегодно необходимо изготовить более 10000 пакетов, а на все работы требуется около 436 чел.-ч, тогда как при новом способе посева
- 128 чел.-ч. В результате трудоемкость этого процесса снизилась в 3,4 раза, уменьшились и затраты на заработную плату, так при ручном посеве в совокупности с подготовкой питомника общие затраты на заработную плату составили 146400 рублей, а новый способ посева позволил сэкономить 94208 рублей (таблица 1).

К сожалению, очень сложно провести оценку качества посева (по глубине закладки семян). Однако возможно утверждать, что качество посева при новом способе значительно лучше, поскольку ручной посев во многом связан с субъективными факторами. Так при посеве сеялкой ССФК-7 семена высеваются в рядки на относительно одинаковую глубину, тогда как при ручном посеве его глубина разная, поскольку самый трудоемкий этап - разгребание поверхностного слоя почвы - невозможно сделать одному человеку, да и с накоплением усталости работника глубина посева, вероятно, меняется.

Выводы. Анализ результатов исследования показал большую практическую ценность нового способа посева сеялкой ССФК-7 для закладки селекционных питомников ранних этапов, а также питомников первичного семеноводства. Эффективность данного способа характеризуется сокращением времени на посев и трудоемкости в 1,9 раза, а экономия зарплаты в 2017 г. составила 94208 рублей. Несомненно, что данный способ посева в дальнейшем необходимо совершенствовать и внедрять в селекционный процесс не только по ячменю, но и по другим культурам. Совершенствование селекционного процесса и замена ручного труда на механизированный позволит в перспективе значительно увеличить объемы селекции и как результат - добиться высоких показателей в селекции. 


\section{DOI: 10.31563/1684-7628-2018-46-2-44-49}

\section{Библиографический список}

1. Бехтольд, Н.П. Изучение исходного материала ярового ячменя для селекции на устойчивость к головневым заболеваниям в лесостепи Приобья [Текст]: автореф. дис. ... канд. с.-х. наук. Барнаул, 2017. С. 6.

2. Кобылянский, В.Д. Изучение инновационной зернофуражной низкопентозановой озимой ржи [Текст] / В.Д. Кобылянский, О.В. Солодухина, Г.Н. Потапова, И.В. Ткаченко, К.А. Галимов // Пермский аграрный вестник. 2014. № 1 (5). С. 12.

3. Ковтунов, В.В. Оценка коллекционных образцов сорго зернового на скороспелость [Текст] / В.В. Ковтунов, О.А. Лушпина, Н.Н. Сухенко // Зерновое хозяйство России. 2015. № 4. С. 31.

4. Филиппов, Е.Г. Селекция ярового ячменя [Текст] / Е.Г. Филиппов, А.В. Алабушев. Ростов н./Д: Книга, 2014. С. 49-50.
5. Комарова, Г.Н. Результаты изучения коллекционного материала для селекции овса [Текст] / Г.Н. Комарова, А.В. Сорокина // Сибирский вестник сельскохозяйственной науки. 2014. № 3. C. 50.

6. Сочалова, Л.П. Генофонд источников устойчивости мягкой пшеницы к листовым заболеваниям [Текст] / Л.П. Сочалова, И.Е. Лихенко // Достижения науки и техники АПК. 2013. № 6. С. 3-6.

7. Семенова, А.Г. Источники устойчивости ячменя к вредным организмам в СевероЗападном регионе России [Текст] / А.Г. Семенова, И.О. Юдин, С.Ю. Орлов // Известия Санкт-Петербургского государственного аграрного университета. 2015. № 38. С. 24.

8. Донцова, А.А. Особенности наследования массы 1000 зерен гибридами $\mathrm{F}_{1}$ и $\mathrm{F}_{2}$ ярового ячменя [Текст] / А.А. Донцова, Е.Г. Филиппов, Д.П. Донцов // Молодежь и наука. 2014. № 2. С. 3.

\section{Сведения об авторе}

Максимов Роман Александрович, кандидат сельскохозяйственных наук, ведущий научный сотрудник лаборатории селекции ячменя, ФГБНУ Уральский научно-исследовательский институт сельского хозяйства, 620061, Екатеринбург, пос. Исток, ул. Главная, 21, тел.: 8 (343) 252-77-77.

В статье рассматривается новый способ посева на ранних стадиях селекции ячменя. Исследования проведены в 2017 г. в стационарном опыте Красноуфимского селекционного центра. Для посева в качестве исследуемой культуры использовали ячмень. Способы посева: ручной (метод «в трубу») и механизированный (сеялкой ССФК-7). В конструкцию высевающего аппарата ССФК-7 добавились пластмассовые воронки, которые располагаются в аппарате порционного высева, плотно прилегая к лопастям ячеек. Пластмассовые воронки располагаются равномерно, так чтобы расстояние между ними было одинаковое, они двигаются по кругу, что обеспечивает рассев семян порциями, каждая порция - линия или семья. Семя- провод, который идет от аппарата порционного высева к центробежному распределителю семян, отсоединяется, вместо него патрубок соединяется с крестовиной, которая распределяет семена на два крайних правых сошника, остальные сошники в данном способе посева не рабочие. Анализ результатов исследования показал большую практическую ценность нового способа посева сеялкой ССФК-7 для закладки селекционных питомников. Эффективность данного способа характеризуется сокращением времени на посев и трудоемкости в 1,9 раза. Совершенствование селекционного процесса и замена ручного труда на механизированный позволит в перспективе значительно увеличить объемы селекции и добиться высоких результатов.

\section{R. Maksimov}

\section{NEW METHOD OF BARLEY SEEDING AT EARLY BREEDING STAGES UNDER THE CONDITIONS OF THE MIDDLE URALS}

\section{Key words: barley; breeding; SSFK-7 seeding-machine; hand sowing; mechanized sowing.}

\section{Authors' personal details}

Maksimov Roman, Candidate of agricultural sciences, Leading Researcher of Laboratory of Barley breeding, Federal State Budgetary Scientific Institute Ural Scientific Research Institute of Agriculture, 620061, Ekaterinburg, Istok village, Glavnaya st., 21, phone: (8343) 252-77-77. 


\title{
DOI: 10.31563/1684-7628-2018-46-2-44-49
}

The article considers a new method of sowing in the early stages of barley breeding. The experimental research was carried out in 2017 in the Krasnoufimsky breeding center. Barley was used as the test culture for seeding. Methods of sowing that have been used were as follows: manual method (method «in the pipe») and the method with the use of the mechanized seeder SSFK-7. In the design of the sowing device SSFK-7, plastic funnels were added, which are located in the apparatus of batch sowing, snug against the blades of the cells. Plastic funnels are located evenly, so that the distance between them is the same, they move in a circle, which ensures the seeding of the seeds in portions, each being a line or a family. The seed tube that goes from the batching machine to the centrifugal seed distributor is disconnected, instead of it the branch pipe is connected to the cross, which distributes the seeds to two extreme right coulters, the other openers in this seeding method are not working. Analysis of the research results showed great practical value of the new method of seeding with the SSFC-7 seeder for the selection of breeding nurseries. The effectiveness of this method is characterized by a reduction in sowing time and labor intensity by 1,9 times. The improvement of the selection process and the replacement of manual labor with mechanized labor will make it possible to significantly increase the amount of selection in the future and to obtain high results in breeding.

(C) Максимов Р.А.

УДК 635.62: 575.174.015.3

DOI: 10.31563/1684-7628-2018-46-2-49-53

А.В. Худякова, А.В. Федоров

\section{ПОДБОР ЭФФЕКТИВНЫХ ISSR-ПРАЙМЕРОВ ДЛЯ ГЕНОТИПИРОВАНИЯ РАСТЕНИЙ СЕМЕЙСТВА ТЫКВЕННЫЕ}

\author{
Ключевые слова: Сисиrbitaceae; ISSR-праймеры; величина информационного полиморфизма; \\ разрешающая способность праймера; дендрограмма генетического сходства.
}

Введение. Тыквенные (Cucurbitaceae) крупное семейство растений, которое включает 960 видов и 125 родов. Виды семейства находят широкое применение: плоды многих из них съедобны (дыни, огурцы, тыквы, арбузы и др.), другие виды используются при изготовлении сосудов и музыкальных инструментов (лагенария), губок и набивочного материала (люффа) и т. п. Некоторые виды обладают лекарственными свойствами или разводятся как декоративные растения (переступень, люффа, лагенария) [3]. Для обеспечения более высокой устойчивости к вредителям, неблагоприятным факторам окружающей среды и повышения урожайности овощных культур зачастую применяют метод прививки [10]. Привитое растение состоит из двух частей: нижней, образующей корневую систему и называемой подвоем, и верхней части привитого растения, формирующей надземные органы, - привоя [2]. Успех срастания и последующего роста прививки зависит от степени совместимости привоя и подвоя. Существует несколько классификаций несовместимости прививки. Согласно одной из них выделяют механическую, выражающуюся в недостаточном срастании, и физиологическую несовместимость, которая ведет к снижению длины приростов и к отставанию в росте. Од- ной из причин последней является генетическая отдаленность прививаемых компонентов и, как следствие, несоответствие их жизненных ритмов, особенно в сроках наступления периода покоя [4, 9]. Для выявления несовместимости привоя и подвоя используют визуальные и физиолого-биохимические методы диагностики $[2,10]$. Однако в последнее время предпочтение получили молекулярно-генетические методы оценки генетической совместимости на основе полимеразной цепной реакции (ПЦР) с применением ДНК-маркеров. Так, отбор подвоев, близких по профилю ДНК с привоем, активно развивается в отношении плодово-ягодных культур [1, 11]. Подобные работы, связанные с изучением генетического разнообразия растений семейства Cucurbitaceae c целью установления наилучших привойно-подвойных комбинаций, в доступной литературе отсутствуют.

Одним из наиболее эффективных инструментов оценки генетического полиморфизма являются микросателлиты, которые относятся к высокополиморфным маркерам растительных геномов [15]. Метод ISSR-типирования (InterSimple Sequence Repeat) является быстрым, экономически выгодным, не требует предварительного клонирования и секвенирования 